\title{
FENOMENA NABI DAN KENABIAN DALAM PERSPEKTIF ALQURAN
}

\author{
Eni Zulaiha \\ Fakultas Ushuluddin UIN Sunan Gunung Djati Bandung \\ J1. AH. Nasution No. 105 Bandung \\ Email: eni.zulaiha@uinsgd.ac.id
}

\begin{abstract}
Prophetic discussion in Islam is a fundamental understanding in Islamic doctrins. The discourse of prophetic is usually discussed under philosophical study. However, in fact, this topic can be discussed by tracing its based on Quranic verses and Hadith. In phiosophical discussion, prophetic is viewed through its epistemological point of view, while in the Qur'an it can be studied through the prophetic terms and missions. This study shows that Prophetic in the Qur'an is represented by the term Naby and Rasul. Naby is derived from naba' which means information, news or story. Meanwhile, Rasul (pl. Rusul) means messenger. Alquran also used the term al-mursalin to indicate the person who sent as messengers. Disputes among Muslim scholars in this issues related to the number of nabi and rasul as well as the qualities assigned to them.
\end{abstract}

Keywords:

Wahyu; ilham; Nabi; Siddiqah; Rasul; Prophet; Prophethness; wali.

\begin{abstract}
Abstrak
Bahasan kenabian dalam Islam adalah jantung bagi pemahaman ajaran agama Islam lainnya. Wacana tentang kenabian biasanya menjadi pembahasan pada kajian filsafat. Padahal wacana ini juga bisa didekati dengan dengan kajian ayat ayat Alquran dan hadis. Jika filsafat kenabian membahas masalah ini dengan sangat kritis dari sisi epistemologisnya, maka dalam Alquran pembahasan tentang kenabian lebih pada persoalan istilah yang digunakan juga misi kenabian yang dibawa oleh masing-masing nabi dan rasul tersebut. Kenabian dalam Alquran menggunakan istilah nabi dan Rasul. Istilah Nabi berkaitan dengan kata naba' yang maknanya berita, kabar, warta atau cerita. Sedangkan Rasul, secara harfiah berarti pesuruh atau diutus. Kata jamaknya adalah rusul. Alquran sering pula menyebut para rasul itu dengan istilah al-mursalin, yaitu mereka yang diutus.perdebatan para ulama ada pada seputar pembahasan nabi dan rasul, jumlah mereka dan persamaan atau keunggulan para nabi.
\end{abstract}

Kata Kunci:

Wahyu; ilham; Nabi; Siddiqah; Rasul; Prophet; Prophethness; wali.

\section{A. PENDAHULUAN}

Islam is no longer understood merely in terms of doctrinal and historical, but it has become a complex phenomenon. ${ }^{1}$ Alquran yang diyakini sebagai wahyu oleh pemeluknya, hanya dapat dikaji sejauh telah "dibudayakan" dalam bahasa manusia dengan "toleransi' tujuh ahruf. Fenomena lahirnya nabi palsu sekarang ini sebenarnya bahasan yang sudah klasik. Topik ini sudah dibahas oleh para cendikiawan muslim terdahulu hingga abad moderen. Kajian tentang perbedaan nabi dan rasul juga wali melahirkan

\footnotetext{
${ }^{1}$ Masripah, "Indonesian Islamic Women Movement (A Case Study of Bkswi West Java)," International Journal of Nusantara Islam 1, no. 2 (2013): 9-21.
}

perdebatan yang panjang di dunia Islam. Pendek kata, diskursus tentang kenabian dalam kajian tafsir Alquran dan hadits telah banyak melahirkan pemahaman yang beragam serta sektarianis. Menurut penulis, pembahasan kembali kenabian hari ini masih diperlukan, fenomena yang cukup meresahkan terjadi di masyarakat kita, yakni dengan bermunculan orang yang mengaku nabi atau wali. Parahnya setelah itu mereka melakulan tindakan penipuan materil atau melakukan pelecehan seksual.

Keresahan yang lahir di tengah masyarakat terkait persoalan nabi palsu, menurut penulis merupakan kenyataan pada adanya kebutuhan pembahasan yang tuntas tentang nabi dan 
kenabian dalam ajaran Islam. Oleh karena itu pembahasan nabi dan kenabian dalam agama Islam bagaikan jantung dalam tubuh manusia. Ia memiliki peran penting karena bersangkutan dengan misi suci penerimaan wahyu juga penegakan batas- batas ajaran yang dianggap benar dan sesuai ajaran Allah. Hampir semua ajaran dasar agama Islam bermuara pada persoaln nabi dan kenabian, misalnya tafsir, hadits, tasawuf, filsafat. Pendek kata diperlukan rumusan yang jelas dan tuntas pada persoalan tersebut. Rasulullah merupakan sosok sentral yang wajib ditaati oleh seluruh umat Islam. ${ }^{2}$.

Tulisan ini akan menitikberatkan kajiannya pada pengertian nabi dan kenabian dalam Alquran dan Hadits. Hal ini agar dapat mengingatkan kembali prinsip-prinsip primordial bahasan ini. Sehingga tulisan ini diharapkan bermanfaat untk memberikan informasi yang komperhensip persoalan kenabian berdasarkan pada dalil-dalil aqli dan naqli. Dan lebih jauh dharapkan dapat mencounter pemikran lain yang akan mengakibatkan lahirnya kembali nabi palsu.

Tema-tema yang akan dibahas dalam tulisan ini berkisar seputar pengertian nabi dan Rasul, karakteristik kenabian dalam Alquran, Misi kenabian dan Ayat-ayat Alquran tentang Nabi, dengan menggunakan metode Deskriptif analitis. Segmentasi tulisan ini adalah para pengkaji keagamaan dengan perspektif Alquran dan hadits. Maka dari itu, tulisan ini tidak menghadirkan perpektif filsafat atau ilmu lainnya dalam pembahasannya.

Tulisan ini membahas pengertian nabi dan Rasul, karakteristik kenabian dalam Alquran, Misi kenabian dan Ayat-ayat Alquran tentang Nabi.

\section{B. HASIL DAN PEMBAHASAN \\ 1. Pengertian Nabi}

Secara etimologis, kata nabi berasal dari bahasa Arab, naba', berarti warta (al-khabar, news), berita (tidings), informasi

\footnotetext{
${ }^{2}$ Sihabuddin Afroni, "Makna Ghuluw Dalam Islam: Benih Ekstremes Beragama," Wawasan: Jurnal Ilmiah Agama Dan Sosial Budaya 1, no. 1 (2016): 71.
}

(information), laporan (report) ${ }^{3}$. Dalam bentuk transitif (anba' 'an) ia berarti memberi informasi (to inform), meramal (to predict), to foretell (menceritakan masa depan), dan istanba'a (meminta untuk diceritakan). ${ }^{4}$ Kata nabi ini bentuk jamaknya nabiyyūn dan anbiya $\bar{a}^{\prime}$. Sedangkan nubuwwah adalah bentuk masdar (kata benda, noun) dari naba, bermakna kenabian (prophecy, ramalan atau prophethood, kenabian), sifat (hal) nabi; yang berkenaan dengan nabi. ${ }^{5}$

Dalam bahasa Inggris, nabi biasa disebut dengan prophet berarti seseorang yang mengajarkan agama, dan mengklaim, mendapat inspirasi ataupun petunjuk dari Tuhan dan prophetess sebutan untuk nabi perempuan; ${ }^{6}$ dan dalam bahasa Yunani prophetes yang berarti orang yang berbicara atas nama orang lain. Dalam hal ini, ia berarti "orang yang mengkomunikasikan wahyu Tuhan." Kata prophetes diterjemahkan ke dalam bahasa Hebrew menjadi kata 'nabi'. Ditinjaud darietimologis berarti "memanggil", "berbicara dengan keras". Ada juga yang mengartikan sebagai "orang yang dipanggil Tuhan untuk berbicara atas namanya". ${ }^{7}$

Menurut Mawlana Muhammad 'Ali, kata nabi berasal dari kata naba'a (jamaknya anbiy $\bar{a}^{\prime}$ ) yang artinya adalah " membertahukan sesuatu yang besar faedahnya," menyebabkan

\footnotetext{
${ }^{3}$ Abdullah Ibn Manzhur, Lisan al-'Arab, vol. VI (Beirut: Dar Sadir, [t.t]), 561; Hans Wehr, A Dictionary of Modern Written Arabic (Wiesbaden: Otto Harrassowitz, 1971), 937.

${ }^{4}$ Hans Wehr, A Dictionary, 937.

${ }^{5}$ David A. Kerr, "Prophethood" in John L. Esposito (ed.), Oxford Encyclopedia of the Modern Islamic World, vol. iii, 364; T. Fahd, "Nubuwwa," dalam Bernard Lewis (ed.), The Encyclopedia of Islam, vol. viii (Leiden: t.p, 1995), 93; Tim Penyusun Kamus Pusat Pembinaan dan Pengembangan Bahasa, Kamus Besar Bahasa Indonesia, Edisi Kedua (Jakarta: Balai Pustaka, 1994), 679.

${ }^{6}$ A.S. Hornby, Oxford Advanced Learner's Dictionary of Current English, Jonathan Crowther (ed.) (Oxford: Oxford University Press, 1995), 929.

${ }^{7}$ David E. Aune, "Prophet, Prophecy," Everett Ferguson (ed.), Encyclopedia of Early Christianity, ed. 6 (New York and London: Garland Publishing, Inc, 1997), 952; Felix N. Nwahaghi, "Priesthood and Prophecy in Judeo-Christian Religion," Journal of Dharma 15 (1990), 5.
} 
orang-orang mengetahui sesuatu. Imam alRaghib al-Asfahani dalam kitabnya alMufradāt fì Gharīb al-Qur'ān menambahkan bahwa maksud berita ialah bukan berita biasa, tetapi berita yang tidak mungkin salah. ${ }^{8}$

Istilah nabi, Gibb dan Kramers memberikan pendapat yang berbeda. ${ }^{9}$ Mereka mengatakan bahwa kata nabi merupakan pinjaman dari istilah Ibrani, nabi dan Aram $n-b-a$. Istilah ini baru muncul pada ayat-ayat periode Makkah kedua. Tetapi keduanya tidak menjelaskan apa arti kata itu. Memang, Alquran sering meminjam istilah-istilah non-Arab, seperti bahasa Ibrani.Tetapi setelah ditampilkan dalam Alquran, istilah-istilah itu selalu mengandung muatan makna baru yang berbeda dari arti lamanya. Realitas kehidupan sosial menjadi mungkin karena ia mengakomodasi perbedaan dan keragaman di antara manusia. ${ }^{10}$.

Secara istilah, kata nabi memiliki banyak definisi. Nabi adalah seseorang yang menerima wahyu dari Allah SWT melalui perantaraan malaikat atau ilham maupun mimpi yang benar. Mereka juga adalah mubasysyir (pembawa berita baik, yaitu mengenai ridha Allah dan kebahagiaan hidup di dunia serta di akhirat bagi orang-orang yang mengikutinya) dan mundzir (pemberi peringatan, yaitu pembalasan bagi mereka serta kesengsaraan terhadap orang-orang yang ingkar) (QS. al-Baqarah [2]: 213). ${ }^{11}$

Kata $n a b \bar{\imath}$ terulang 75 kali dalam 20 surat, sedangkan kata naba' terulang 29 kali dalam 21 surat. Salah satu ayat yang menyebut kata nabi adalah terdapat dalam surat Maryam [19]:

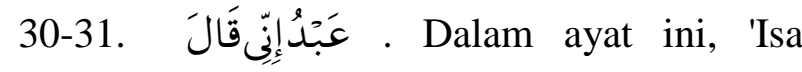
menjelaskan bahwa dirinya sebagai seorang hamba Allah biasa, maksudnya bukan putra Allah, dia telah pula diberi Kitab, yakni Injil

${ }^{8}$ M. Dawam Rahardjo, Ensiklopedi alQur'an (Jakarta: Paramadina, 1997), 303.

${ }^{9}$ H.A.R. Gibb dan J.H. Kramers, Shorter Encyclopedia of Islam (Leiden: E.J. Brill, 1974).

10 Casram, "Membangun Sikap Toleransi Beragama," Wawasan: Jurnal Ilmiah Agama Dan Sosial Budaya 1, no. 2 (2016): 187.

${ }^{11}$ Departemen Agama RI, Ensiklopedi Islam Indonesia (Jakarta: Depag, 1987-1988), 659. dan ditetapkan sebagai seorang nabi. Dengan begitu, 'Isa merupakan orang yang diberkati Allah dan dia merasakan berkat itu. Dan mempunyai misi kenabian, yang tujuannya untuk menegakkan shalat dan menunaikan zakat. Seperti dijelaskan sebelumnya bahwa pengertian tentang istilah nabi, berkaitan dengan kata naba' yang maknanya berita, kabar, warta atau cerita. Makna sesungguhnya dari kata naba' ini perlu dilihat dalam konteks ayat-ayat Alquran sendiri, ${ }^{12}$ seperti misalnya dalam surat Ali Imran [3]: 43

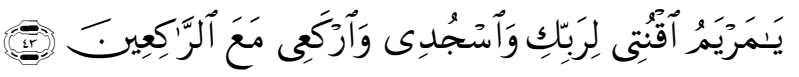

"Ini adalah sebagian berita (naba',) yang telah kami wahyukan kepadamu. Engkau tidak berada di antara mereka tatkala melemparkan pena mereka (untuk menentukan) siapa diantaranya yang akan memelihara Maryam, begitupula engkau tidak berada di antara mereka ketika bertengkar satu sama lain." (Ali Imran [3]: 43).

Pembicaraan tentang terma nabi (an-nabī, prophet) dan kenabian (an-nubuwwah, prophecy/prophethood) tidak terlepas dari term rasul (ar-rasul, apostol) dan kerasulan (ar-risālah, apostolos).Banyak yang menyamakan antara keduanya dan dengan demikian dapat dipakai secara bergantian, namun tidak sedikit pula yang melakukan pembedaan.Namun secara umum, nabi dan rasul adalah manusia yang dipilih Allah SWT untuk menerima dan menyampaikan wahyu Allah. ${ }^{13}$

Secara tradisional, penulis-penulis Muslim mengenai Alquran membuat sebuah perbedaan antara nabi dan rasūl. Nabi ialah utusan Allah yang tidak membawa hukum (syari'at) dan mungkin pula kitab Allah kepada manusia; sedang rasul yang bentuk jamaknya rasūl, dalam pengertian bahasa berarti utusan, dan menurut istilah ialah utusan Allah yang membawa hukum dan kitab Allah sebgai pedoman manusia. Atau menurut pendapat yang masyhur, nabi adalah orang

\footnotetext{
${ }^{12}$ M. Dawam Rahardjo., Ensiklopedi, 303.

${ }^{13}$ Taufik Abdullah (ed), Ensiklopedi Tematis Dunia Islam (Jakarta: PT. Ichtiar Van Houve, 2000), 14.
} 
yang menerima wahyu dari Allah SWT tanpa kewajiban menyampaikan kepada orang lain, sedangkan rasul adalah orang yang mendapatkan wahyu dari Allah yang mempunyai kewajiban menyampaikannya kepada manusia. ${ }^{14}$ Batasan ini menunjukkan bahwa nabi menyampaikan wahyu Allah kepada kaumnya melalui keteladanan pribadi yang terbentuk atas bimbingan wahyu, sedang rasul, disamping keteladanan, mereka dituntut pula menyampaikan wahyu yang diterimanya secara aktif. Islam autentik dicirikan terutama sekali oleh seruan kembali kepada sumber ajaran Islam utama ${ }^{15}$.

Dalam ensiklopedia karya Cyril Glasse, The Concise Encyclopedia of Islam, makna nabi merupakan seseorang yang menjalankan tugas kenabiannya dalam bingkai wahyu yang telah ada, berlawanan dengan rasul, yang membawa wahyu yang baru. ${ }^{16}$ Rasūl, secara harfiah berarti pesuruh atau diutus. Kata jamaknya adalah rusul.Alquran sering pula menyebut para rasul itu dengan istilah almursalin, yaitu "mereka yang diutus". Seorang rasul, menurut Glasse mengemban misi membawa religi baru atau wahyu baru dalam konteks masyarakatnya.Mereka itu disebut juga ulual-'azm (QS. Al-Ahqaf [46]: 35). Menurut al-Tabary, disebut ulul 'azmi karena mereka mempunyai kesabaran dan keuletan dalam menghadapi berbagai cobaan ketika menyampaikan amr al-ma'rüf wan nahy 'an al-munkar. ${ }^{17}$

Selanjutnya, di antara orang yang membedakan dua terma tersebut adalah Muhammad 'Ali ash-Shabuni. Menurutnya, nabi adalah seseorang yang mendapat wahyu dari Allah berupa hukum syari'at, tetapi tidak dibebani untuk menyampaikannya, sedang

\footnotetext{
${ }^{14}$ Depag RI, Ensiklopedi Islam Indonesia, 659.

15 Aceng Abdul Kodir, "Sejarah Bid'ah: Ashhab AL-Hadith Dan Dominasi Wacana Islam Autentik Pada Tiga Abad Pertama Hijriyah," Wawasan: Jurnal Ilmiah Agama Dan Sosial Budaya 1, no. 2 (2016): 212.

${ }^{16}$ Cyril Glasse, The Concise Encyclopedia of Islam (San Francisco: Harper \& Row, Publishers, Inc, 1989), 342.

${ }^{17} \mathrm{Abu}$ Ja'far Muhammad b. Jarir al-Thabari, Jami' al-Bayan 'an Ta'wil ay al-Qur'an, vol. 13, (Beirut: Dar al-Fikr, 1988), 37.
}

rasul adalah seseorang yang mendapat wahyu dari Allah berupa hukum syari'at tetapi diperintahkan untuk menyampaikannya. ${ }^{18}$ Lain lagi definisi yang diberikan oleh al-Bazdawi yang menyatakan bahwa rasul adalah seseorang yang didatangi oleh Jibril untuk menjadikannya sebagai rasul bagi suatu kaum dan supaya mengajak kaum tersebut kepada Islam dan mengajarkan kepada mereka hukum syari'at. Sedang nabi adalah seseorang yang mendapat ilham dari Allah (tanpa perantara Jibril) atau melalui mimpi, atau berdasarkan khabar dari rasul bahwa ia seorang nabi yang mempunyai tugas untuk mengajak umatnya kepada Islam. ${ }^{19}$ Sedangkan menurut Ibn Tahir at-Tamimiy al-Bagdadiy, nabi adalah orang yang mendapat wahyu dari Allah melalui malaikat dan rasul adalah orang yang diberi syari'at untuk memulai atau menghapus sebagian syariat sebelumnya. ${ }^{20}$

Untuk menguatkan pendapatnya, mereka mengajukan argumen di antaranya hadis Nabi Saw.yang menyebutkan jumlah nabi itu 124.000 sedangkan jumlah rasul ada 315. ${ }^{21}$ Argumen lain adalah QS. Al-Hajj [22]: 52 yang menyebutkan nabi dan rasul secara terpisah,

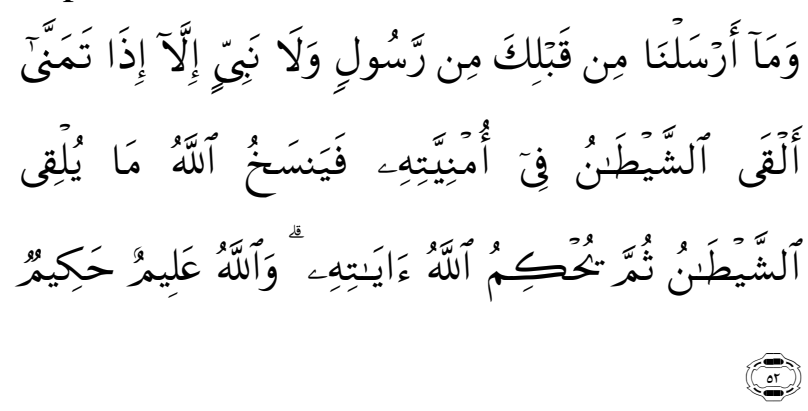

"Dan Kami tidak mengutus sebelum engkau seorang rasulpun dan tidak pula seorang nabi kecuali apabila dia menginginkan (membaca), maka syetan mengganggu keinginannya..."

\footnotetext{
${ }^{18}$ Muhammad 'Ali ash-Shabuni, An-Nubuwwah wa al-Anbiya' (Beirut: 'Alim al-Kutub,1985), 14.

${ }^{19} \mathrm{Abu}$ al-Yusr Muhammad bin Muhammad bin Abdul Karim al-Bazdawi, Kitab Usul ad-Din (Kairo: Dar Ihya al-Kutub al-'Ilmiyyah, 1963), 223.

${ }^{20} \mathrm{Abu}$ Mansur Abdul Qahir ibn Tahir at-Tamimi alBagdadi, Kitab Usul ad-Din (Beirut: Dar al Kutub al'Ilmiyah, 1981), 154.

${ }^{21}$ Hadis Shahih diriwayatkan oleh Imam Ahmad bin
} Hanbal. 
QS. Maryam [19]: 51.

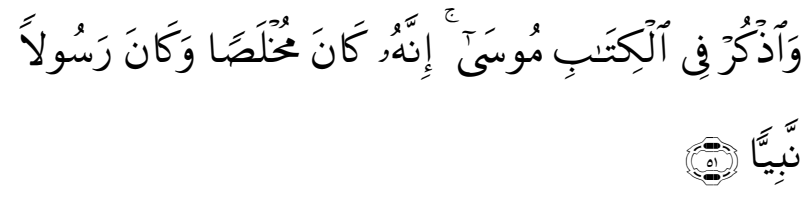

"Dan ingatlah (berita) Musa dalam Kitab; sesungguhnya dia adalah seorang yang terpilih dan dia adalah seorang rasul dan nabi."

Bagi mereka, jika sebagian nabi disifati sebagai nabi sekaligus rasul, maka itu menunjukkan bahwa rasul itu lebih daripada sekedar nabi, yakni risalah mempunyai kedudukan lebih tinggi daripada kenabian.Setiap rasul adalah nabi namun tidak setiap nabi adalah rasul. Dengan demikian tentunya jumlah rasul tentu lebih sedikit daripada nabi. $^{22}$

Yang menjadi alasan kelompok yang membedakan antara nabi dan rasul bagi pendapatnya bahwa baik nabi maupun rasul keduanya dituntut untuk menyampaikan (tabligh). 2) Mengabaikan tugas penyampaian berarti menyembunyikan (kitmān) wahyu Allah. Dalam hal keyakinan eskatologis, ahli hadis meyakini hanya berdasarkan pemberitaan wahyu sesuatu bisa diyakini. Padahal Allah menurunkan wahyu untuk disebarluaskan, bukan untuk disimpan dalam diri sendiri. 3) Sabda Nabi SAW.:

"Telah diperlihatkan kepadaku umat-umat

di mana kulihat seorang nabi yang disertai

banyak pengikut, nabi yang diikuti oleh

satu dua orang serta nabi yang tidak ada

pengikutnya."

Hadis di atas juga menunjukkan bahwa para nabi itu diperintahkan untuk menyampaikan wahyu-nya.Selanjutnya dia mengemukakan definisi yang cukup bagus bahwa rasul adalah orang yang mendapat wahyu dari Allah berupa syari'at yang baru; sedangkan nabi adalah seorang yang diutus untuk meneguhkan dan melanjutkan syari'at sebelumnya.

\footnotetext{
${ }^{22}$ Umar Sulaiman al-Asygar, Al-Rusul wa al-Risalat (Kuwait: Maktabah al-Falah, 1985), 14.
}

Adapun mereka yang menyamakan dua term tersebut berargumen pada: pertama, QS. Al-Muddassir [74]:12.

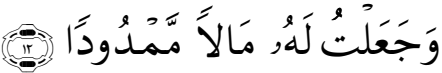

"Hai orang yang berkemul (berselimut). Bangunlah, lalu berilah peringatan!"

Ayat tersebut secara jelas memerintahkan nabi untuk berdakwah dan memberi peringatan.Kata Nabi yang merupakan derivasi dari kata $n a b a$, yang berarti bahwa Allah memberikan kabar kepadanya melalui wahyu kepada siapa saja yang dikehendaki (QS. At-Taubah [9]: 94),
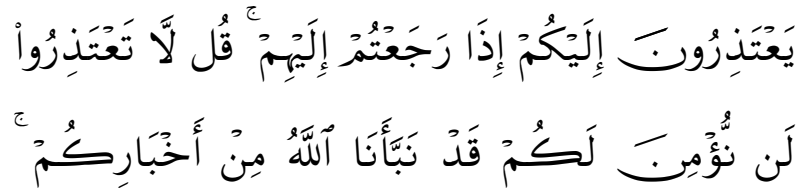

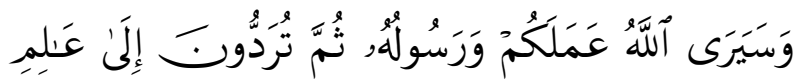

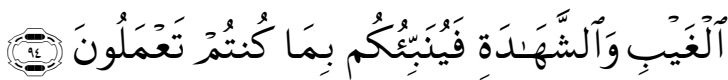

" Mereka mengemukakan 'uzurnya kepadamu, jika Telah kembali kepada mereka (dari medan perang). Katakanlah: "Janganlah kamu mengemukakan(alasan) 'uzur; kami tidak percaya lagi kepadamu, (karena) Allah telah memberitahukan kepada kami informasi yang sebenarnya. Allah serta rasulnya akan melihat pekerjaanmu, Kemudian kamu dikembalikan kepada yang Maha Nengetahui lagi ghaib serta yang nyata, lalu dia memberitahukan kepadamu apa yang Telah dikerjakan."

Berdasarkan ayat di atas, maka nabi mempunyai tugas menyampaikan apa saja yang diwahyukan kepadanya. Oleh karena itu, setiap nabi wajib menyampaikan apa yang diwahyukan kepadanya berupa syari'at. Jika tabligh (penyampaian) merupakan buah dari kenabian, maka tidak ada dalam hukum Allah orang yang diberi wahyu tapi tidak diperintahkan untuk menyampaikannya. ${ }^{23}$

\footnotetext{
${ }^{23}$ Syaikh Abdullah bin Zaid Ali Mahmud, al-Ittihaf Ahfiya' bi Risalah al-Anbiya' (Qatar: Ri'asah alMahakim asy-Syar'iyyah wa asy-Syu'un ad-Diniyyah, 1991), 4
} 
Hal ini diperkuat oleh pendapat 'Umar Sulaiman al-Asyqar, walaupun dia juga membedakan terma nabi dan rasul, namun pembedaan ini bukan terletak pada adanya tuntutan menyampaikan wahyu atau tidak, sebagaimana definisi yang umum, tapi lebih pada isi wahyu atau syariat yang dibawa. Dia berargumen di antaranya: 1) QS. Al-Hajj [22]: 52: sebagaimana disebut di atas. 285.

Demikian juga dalam QS. Al-Baqarah [2]:

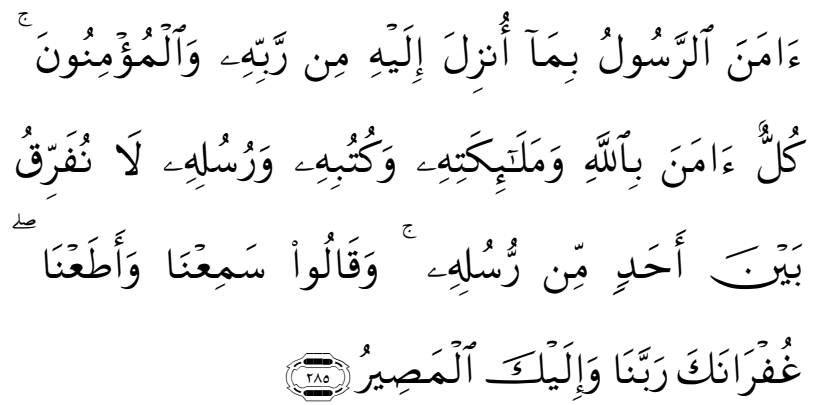

Dalam ayat 285 disebut dengan istilah rusul dan ayat 283 dengan istilah nabi, namun hakikatnya adalah sama (an-Nabiyyūn sama dengan al-Mursalin). Maksud ayat ini adalah larangan membeda-bedakan di antara para nabi atau rasul.Menyebut sebagian mereka yang mendapat wahyu dari Allah sebagai nabi, karena tidak diperintahkan untuk menyampaikannya; sedang sebagian lainnya adalah nabi sekaligus rasul karena mendapat perintah menyampaikan, dalam hal ini adalah dianggap sebagai pembedaan. ${ }^{24}$

Menurut Murtadha Mutahhari, nabi adalah seorang manusia yang bertindak sebagai penerima wahyu dan kemudian menyampaikan pesan-pesan Tuhan (baca: wahyu) kepada umat manusia. Nabi adalah manusia pilihan yang memenuhi prasyarat untuk menerima pesan-pesan tersebut dari alam gaib. ${ }^{25}$ Pengutusan para nabi atau rasul oleh Tuhan merupakan adanya garis perbedaan antara Tuhan dan makhluk. Dalam hal tersebut, Hammudah Abdalati menyatakan tujuan kenabian adalah menunjukkan apa yang harus atau yang dapat diketahui manusia dan

\footnotetext{
${ }^{24}$ Al-Asyqar, Al-Rusul.

${ }^{25}$ Murtadha Muthahhari, Falsafah Kenabian (Jakarta: Pustaka Hidayah, 1991), 9.
}

mengajar apa yang tidak atau belum diketahui dan dimengerti. ${ }^{26}$

Dalam Alquran, kata nabi dan rasul selalu digunakan secara bergantian. Hal tersbut ditujukan untuk membedakan artinya, karena ulama melihat dari arti kata ataupun asal katanya, istilah nabi menekankan dari segi kesanggupannya menerima berita Ilahi (wahyu), sedangkan rasul menekankan pada misinya untuk menyampaikan risālah atau nubuwwah pada manusia, adakalanya bukan manusia, melainkan juga malaikat (QS. AlFathir [35]: 1)

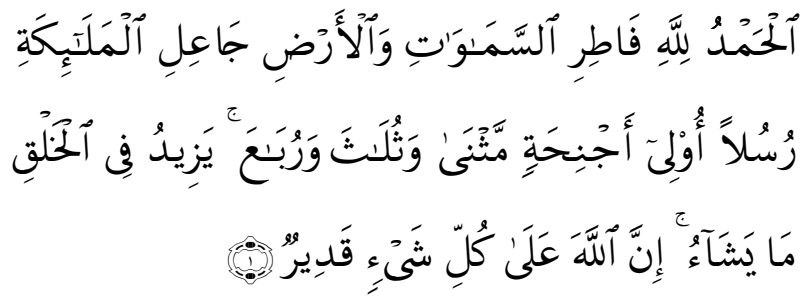

"Segala puji bagi Allah Pencipta langit dan bumi, yang menjadikan malaikat sebagai utusan-utusan (untuk mengurus berbagai macam urusan) yang mempunyai sayap, masing-masing (ada yang) dua, tiga dan empat. Allah menambahkan pada ciptaannya apa yang dikehendakinya. Sesungguhnya Allah Maha Kuasa atas segala sesuatu."

Dengan demikian seorang nabi menerima wahyu bagi dirinya sendiri, sedangkan rasul menerima wahyu untuk disampaikan kepada manusia. Salah satu keterangan tentang terma nabi dan rasul dalam Alquran diberikan oleh Alquran surat al-An'am [6]: 89,

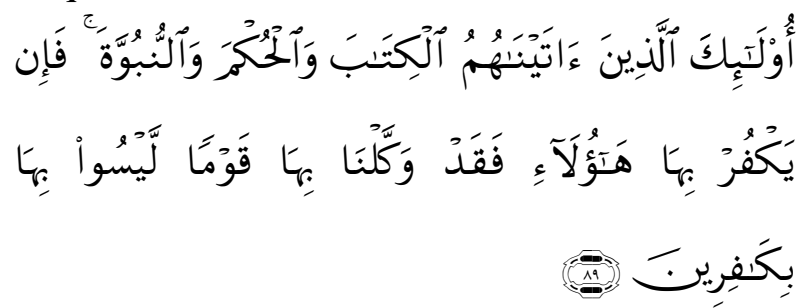

"Mereka orang-orang yang telah kami beri kitab, hukum dan ramalan (nubuwah). Apabila mereka menolak hal (tiga kriteria) tersebut, niscaya kami akan menyerahkannya kepada kaum yang sekali-kali tidak mengingkarinya."

\footnotetext{
${ }^{26}$ Hammudah Abdalati, Islam Dalam Sorotan (terj) Anshari Thayib (Surabaya: Bina Ilmu,1981), 32.
} 
Ayat di atas menjelaskan bahwa nabi itu mempunyai tiga kriteria. Pertama, menerima wahyu yang selanjutnya terhimpun dalam suatu kitab. Kedua, membawa syariat atau hukum untuk pedoman hidup, karena itu teladan nabi dan rasul itu merupakan sumber hukum. Ketiga, memprediksi berbagai hal di masa yang akan datang, hal tersebut dapat terlihat pada Nabi Nuh, Ibrahim atau Luth yang telah memperingatkan umatnya, sekalipun telah didustakan. Nabi Muhammad saw pernah meramalkan dengan tepat kekalahan parsi melawan Roma, berdasarkan wahyu Ilahi Karena itu maka ayat selanjutnya mengatakan: "mereka itulah orang-orang yang telah diberi petunjuk oleh Allah, maka ikutilah petunjuk mereka." QS. Ar-Rum [30]: 2.

Di dalam Alquran, Nabi yang "menyampaikan khabar" bukan berarti "yang menjelaskan keadaan di masa mendatang", melainkan "yang menyampaikan khabar dari Allah". Nabi diutus Allah untuk mencegah kejahatan dan menyampaikan kabar gembira kepada orangorang yang saleh. Itulah sebabnya mengapa istilah-istilah "yang menyampaikan kabar gembira" dan "yang menyampaikan peringatan" sering dinyatakan Alquran, terutama sekali di masa-masa awal kenabian Muhammad. $^{27}$

Rasul mempunyai arti "utusan", atau yang diutus oleh Allah kepada umat manusia walaupun di dalam Alquran perkataan rasul kadang-kadang dikenakan juga kepada malaikat yang menyampaikan wahyu dari Allah kepada Nabi; di dalam pengertian yang terakhir ini istilah sufarā' (plural dari sāfir yang berarti "duta") hanya dipergunakan sekali saja, yaitu di dalam surat 'Abasa (80): 15 .

Sementara bisa disimpulkan bahwa, sebutan rasul menunjukkan peranan yang lebih penting daripada seorang nabi.Seorang nabi dapat berperan sekedar sebagai pembantu rasul, misalnya Harun yang berperan sebagai pembantu Musa (QS. Maryam [19]: 51, 53), walaupun rasul-rasul (atau lebih tepatnya: mursal, "yang diutus") dapat ditugaskan Allah

\footnotetext{
${ }^{27}$ Fazlur Rahman, Tema Pokok al-Qur'an, terj.
} Ahsin Muhammad (Bandung: Mizan, 1996), 119. secara bersama-sama (QS. Al-Ahzab [33]: 13 dan 16)

Terlepas dari perdebatan di atas, kata nabi dan rasūl keduanya digunakan di dalam Alquran. Kadang-kadang disebut nabi, pada waktu lain disebut rasul, dan adakalanya dipakai secara bersamaan. Untuk kepentingan penelitian ini, penulis lebih cenderung menggunakan istilah nabi dan rasul. Nabi dan rasul adalah orang-orang yang dimuliakan oleh Allah karena mereka adalah manusia pilihan. Kenabian dan kerasulan diperoleh seseorang melalui karunia dan pemberian dari Tuhan kepada manusia pilihan-Nya.Kenabian tidak dapat diperoleh melalui usaha dan pengorbanan jerih payah, juga tidak didapat melalui warisan maupun ketaatan beribadah. Adalah merupakan hak Allah semata dalam menentukan dan memilih hamba-nya yang patut dan memikul tanggungjawab kenabian.Yang membedakan keduanya adalah isi wahyu, wahyu yang sampai kepada rasul berupa syariat baru sedangkan wahyu yang datang kepada nabi adalah peneguhan dari syari'at yang telah ada. Hukum Islam diturunkan oleh Allah Swt bertujuan untuk mencegah kerusakan pada manusia dan mendatangkan kemaslahatan bagi mereka, mengarahkan kepada kebenaran, keadilan dan kebijakan serta menerangkan jalan yang harus dilaluinya $^{28}$.

Dalam tradisi Islam yang notabene datang paling belakang di antara tradisi Yahudi dan Kristen, perkembangan kenabian merupakan suatu rangkuman dari pemberitaan yang ada pada wahyu Alquran. Alquran mengakui bahwa risalah kenabian adalah satu dan tidak dapat dibagi (indivisible), dalam arti bahwa para nabi adalah pembawa risalah yang sama dari Tuhan yang sama. ${ }^{29}$ Oleh karenanya, dalam Islam, aspek kepengutusan Tuhan kepada para manusia pilihan untuk

${ }^{28}$ Qosim, “Analysis of Critical Thought Wahbah Wahbah Az-Zuhailī Concerning Determination Separations," Jurnal Studi Agama Dan Masyarakat 10, no. 2 (2016): 233.

${ }^{29}$ Fazlur Rahman, Major Themes of The Qur'an (Minneapolis dan Chicago: Bibliotecha Islamica, 1980), 53, 80 . 
menyampaikan risalah bersifat universal karena setiap bangsa pasti telah datang kepadanya seorang nabi sebagai pemberi kabar berita dan peringatan. (QS. Fatir [35]: 24, Yunus [10]: 47, an Nisa [4]: 164). ${ }^{30}$ Dengan demikian, dalam tradisi Islam, para nabi diyakini telah diutus mulai dari zaman Adam sampai nabi Muhammad sebagai nabi terakhir dalam arti yang sebenarnya.

Nabi adalah manusia pilihan dan yang dimuliakan Allah.Mereka diberi kemampuan untuk berhubungan dengan Allah dan mengekspresikan kehendaknya. ${ }^{31}$ Oleh karena itu, seorang nabi adalah manusia yang bertindak sebagai penerima yang menyampaikan pesan-pesan Tuhan (baca:wahyu) kepada umat manusia. ${ }^{32}$

Oleh sebab itu, seseorang manusia dapat dikatakan sebagai nabi, apabila memenuhi beberapa kriteria. Salah satunya pendapat AlMusayyar yang menjelaskan syarat-syarat seorang nabi atau rasul, yakni: (1) manusia, (2) laki-laki, (3) merdeka (bukan budak), (4) terhindar dari aib (cacat): maksum dari perbuatan dosa dan salah, dan (5) Allah mewahyukan syari'at kepadanya. ${ }^{33}$

Adapun ciri utama nabi ialah mendapat wahyu dari Allah, baik melalui malaikat Jibril, atau lainnya. Sementara ciri lain yang dimiliki nabi ialah mendapatkan mukjizat sebagai perbuatan luar biasa yang muncul pada seorang nabi (yang telah mendapatkan wahyu).

Sedangkan menurut Murtadha Muthahhari, seseorang dapat disebut sebagai nabi, apabila memiliki beberapa karakteristik, $^{34}$ di antaranya:

1) Wahyu (yaitu nabi merupakan seseorang yang diberi wahyu oleh Allah)

Istilah wahyu (al-wahy, revelation) dalam Islam adalah kata yang paling penting dari semua kata-kata Arab yang menunjukkan

\footnotetext{
${ }^{30}$ Rahman, Major Themes, 80.

${ }^{31}$ Ibrahim Madkour, Filsafat Islam Metode dan Penerapan, (terj) Yudian Wahyudi (Jakarta: CV. Rajawali, 1991), 85.

${ }^{32}$ Muthahhari, Falsafah, 9.

${ }^{33}$ Ibn Katsir, al-Bidayah wa al-Nihayah, vol. I, Juz I, cet. I (Cairo: Dar al-Taqwa, 1999), 56, 58, 59, \& 60)

${ }^{34}$ Muthahhari, Falsafah, 1018.
}

fenomena diturunkannya ayat-ayat Tuhan (Alquran) ${ }^{35}$ Berkaitan dengan pewahyuan Alquran, maka kata kunci yang sangat signifikan untuk diperhatikan, selain kata $a w h \bar{a}$ beserta kata turunannya, adalah inzāl dan tanzìl. Dalam Bahasa Arab, bertitik tolak dari asumsi Syahrur "bahwa tidak ada sinonim dalam bahasa", maka elaborasi setiap kata dalam Alquran menjadi sangat penting untuk mendapatkan pengertian secara utuh. ${ }^{36}$ Walaupun kata-kata itu simbolis, tapi makna primernya berbeda.Wahyu berarti 'pertunjukan' atau 'pernyataan' diri Tuhan.Tanzil ialah 'penurunan' nya dari langit ke bumi. Dalam QS. Maryam [19]: 11, awh $\bar{a}$ (kata kerja) digunakan untuk Zakaria ketika mengalami bisu dan secara jelas berarti 'diperlihatkan' atau 'dipertunjukkan dengan suatu tanda'.

Namun demikian, dalam makna sentralnya, wahyu adalah proses komunikasi antar dua pihak yang mengandung pemberian pesan secara samar, rahasia dan sangat pribadi. ${ }^{37}$

Wahyu ilahi merupakan suatu kenyataan yang universal, yang tidak hanya diterima oleh para nabi tertentu dan hanya dimiliki oleh umat keagamaan tertentu. Seperti halnya Nabi Muhammad yang menjadi pemimpin di Mekkah, "The Madina Charter is proof that Prophet Muhammad was a religious leader as well as a political leader". 38 .

${ }^{35}$ Toshihiko Izutsu, Relasi Tuhan dan Manusia, terj. Agus Fahri Husein, dkk, cet. 1 (Yogyakarta: Tiara Wacana, 1997), 171.

${ }^{36}$ Muhammad Syahrur, Al-Kitab wa al-Qur'an: Qira'ah Mu'asirah (Damaskus: AlAhaly, 1990), 47.

${ }^{37}$ Tentang bagaimana proses komunikasi antar berbagai pihak berlangsung, terjadi perdebatan, karena pada dasarnya di antara pihak yang satu berbeda secara ontologis dengan pihak yang lain. Namun demikian, fenomena ini bisa dipahami dan dianggap lumrah oleh masyarakat Arab pada saat itu, di mana peradaban sebelum Islam telah mengenal pola dan mekanisme yang hampir sama dengan wahyu; yaitu komunikasi dengan jin (tajnin). Nasr Hamid Abu Zaid, Tekstualitas al-Qur'an Kritik Terhadap Ulum al-Qur'an, terj. Khoiron Nahdliyyin (Yogyakarta: LKiS, 2001), 34, 43.

38 Fatmawati, "Inter-Religious Relations In The Period Of Prophet Muhammad," Al-Albab 5, no. 2 (2016): 175-193. 
Dalam Islam, kata "wahyu" banyak digunakan dalam Alquran dengan berbagai bentuk, baik dalam bentuk kata benda atau kata kerja. Apabila term wahyu ini dikembalikan kepada pengertian teologi Islam, tentunya dapat diambil dua pengertian dasar yaitu: Wahyu syari'ah dan wahyu bukan syari'ah atau identik dengan istilah ilham. Wahyu Syari'ah, dalam kepercayaan sebagian besar umat Islam, lebih berupa seluruh sabda Tuhan yang diterima oleh para nabi sebelum Muhammad yang berisi hukum-hukum (syari'ah) dan diyakini telah disempurnakan oleh kenabian Muhammad yang kemudian terkodifikasi dalam wujud Alquran. Sedangkan pengertian wahyu yang kedua ini sering oleh sementara kelompok dalam Islam lebih dianggap wahyu yang masih tetap akan turun walaupun sepeninggal Nabi Muhammad Saw. ${ }^{39}$

Kata Wahyu adalah kata benda, dalam bentuk kata kerjanya adalah auha-yuhi, artinya adalah pemberitahuan secara tersembunyi dan cepat (i'lām al-khafī as-sarī̄ $)^{40}$.

Berdasarkan uraian yang telah dipaparkan, dapat dinyatakan bahwa wahyu adalah kenyataan universal, yang tidak hanya diberikan kepada para nabi melainkan diberikan pula kepada semua ciptaannya, termasuk benda-benda tak bernyawa. Dalam pengertian ini, maka mereka membagi wahyu pada lima macam: yaitu, (a) wahyu Tuhan kepada langit dan bumi (QS. Fusjilat [41]: 1112; QS. Al-Zalzalah [99]: 15); (b) wahyu Tuhan kepada binatang (QS. an-Nahl [16]: 6869); (c) wahyu Tuhan kepada para malaikat (QS. Al-Anfal [8]: 12); (d) wahyu Tuhan kepada manusia biasa (QS. Al-Qashas [28]: 7; QS. Al-Maidah [5]: 111) dan (e) wahyu Tuhan kepada para nabi (QS. Al-Anbiya [21]: 7; QS. An-Nisa'[4]:164). ${ }^{41}$

\footnotetext{
${ }^{39}$ Muslih Fathoni, Faham Mahdi Syi'ah dan Ahmadiyah Dalam Perspektif (Jakarta: PT Raja Grafindo Persada, 1994), 108.

${ }^{40}$ Muhammad Ismail Sya'ban, Ma' al-Qur'an alKarim (Kairo: Dar al-Ittihad al-'Arabi li at-Tiba'ah, 1978), 85.

${ }^{41}$ Mulyono, Bunga Rampai Paham Keagamaan Gerakan Ahmadiyah Indonesia (Yogyakarta: Penerbit
}

2) Mu'jizat

Nabi yang diangkat oleh Tuhan diberi anugerah kemampuan luar biasa yang mampu melakukan tindakan-tindakan tertentu yang tidak bisa dilakukan oleh manusia biasa. Hal tersebut menunjukkan kebenaran kenabian dan firman Tuhan yang mereka sampaikan. Perbuatan luar biasa yang dikerjakan oleh para nabi dengan izin Tuhan tersebut, oleh Alquran dinamakan ayat atau tanda kenabian sedangkan para teolog Islam menyebutnya mu'jizat (harfiah: yang membuat orang lain lemah). ${ }^{42}$

\section{3) 'Ishmah.}

Bahwa para nabi itu terjaga dari perbuatan dosa dan kekeliruan yang disebabkan karena pemahaman dan kedalaman iman mereka. Semakin tinggi keimanan dan kesadaran mereka terhadap akibat buruk dari dosa, semakin berkurang kemungkinan melakukan perbuatan dosa. Para nabi memiliki derajat keimanan yang mencapai tingkat intuitif dan pandangan batin sehingga mampu membedakan dan menghindari perbuatan dosa. $^{43}$

\section{4) Kecerdasan}

Kecerdasan dan kemampuan menalar yang dimiliki para nabi berbeda dengan kemampuan orang jenius dalam hal yang sama. Perbedaan yang mendasar ialah bahwa jenius merupakan orang yang mempunyai kemampuan berpikir, daya menalar dan analisis yang tinggi sehingga mampu merumuskan teori-teori dan kemampuan membuat kesimpulan. Para nabi selain memiliki kemampuan di atas juga dilengkapi dengan kemampuan lain yang disebut wahyu. Inilah yang bisa membebaskan mereka dari kekeliruan. $^{44}$

5) Kepemimpinan

Berawal dari misi kenabian tentu akan berujung pada langkah kembali kepada masyarakat dan dunia luar untuk mengorganisasi dan memimpin kehidupan masyarakat

Darul Kutubil Islamiyah bekerjasama dengan LPMAT PIRI, 2003), 21-24.

${ }^{42}$ Muthahhari, Falsafah, 10.
${ }^{43}$ Fahd, "Nubuwwa," 94-95.
${ }_{44}$ Muthahhari, Falsafah, 14. 
pada jalan yang benar. Dalam pengalaman "bersatu" dengan Tuhan, para nabi kembali untuk terjun dalam arus waktu dengan niat untuk mengendalikan kekuatan-kekuatan sejarah dan menciptakan dunia baru yang ideal. Konsekwensinya, memimpin manusia, ialah kemampuan untuk mengelola dan menggerakkan potensi-potensi manusia (masyarakat) ke arah kehendak Tuhan dan demi kebaikan umat manusia, yang merupakan bagian tak terpisahkan dari misi kenabian. Sehingga penyusunan hadist pun tidak terlepas dari sosok nabi atau wali, seperti ungkapan Putra, "sunnah adalah sesuatu yang dipraktikkan secara kontinu (terus-menerus) oleh sosok yang menjadi panutan baik seorang Nabi atau wali ${ }^{45}$.

6) Ketulusan niat

Para nabi memiliki dedikasi yang tinggi dalam mengemban misinya. Mereka tidak meminta imbalan jasa dalam membimbing umatnya menuju Tuhan (QS. Asy-Su'ara [26]: 127); Pesan-pesan mereka selalu bersifat keputusan akhir yang tidak dapat ditawar lagi.

7) Konstruktivitas

Para nabi memberikan energi kepada kekuatan-kekuatan masyarakat dan mengorientasikan mereka agar melatih individu dan membimbingnya, dan membangun masyarakat manusia.

8) Konflik dan Perjuangan

Tanda lain dari ketulusan seorang nabi dalam klaimnya adalah bahwa ia berjuang menentang politheisme, tahayul, kebodohan, kepalsuan, penindasan, kekejaman dan ketidakadilan. Setiap nabi adalah berjuang meneguhkan monotheisme (tauhid), kebijaksanaan dan keadilan. ${ }^{46}$ lazimnya, umat Islam merumuskan sifat-sifat yang harus dimiliki nabi adalah: shiddīq (benar), amānah (bisa dipercaya), tabligh (mampu menyampaikan) dan fathanah (cerdas). ${ }^{47}$

9) Aspek manusiawi

${ }^{45}$ Afriadi Putra, "Pemikiran Hadis KH. M. Hasyim Asy'ari Dan Kontribusinya Terhadap Kajian Hadis Di Indonesia," Wawasan: Jurnal Ilmiah Agama Dan Sosial Budaya 1, no. 1 (2016): 52.

${ }^{46}$ Muthahhari, Falsafah, 15.

${ }^{47}$ As-Sabuni, Kenabian, 66.
Meskipun para nabi memiliki karakteristik seperti di atas, namun mereka adalah manusia biasa. Artinya, mereka memiliki semua karakteristik yang dimiliki oleh seorang manusia; mereka tidak akan hidup selamanya (QS. Al-Anbiya [21] : 8), makan dan minum, pergi ke pasar, serta mempunyai anak dan 'isteri' (QS. Al-Furqan [25]: 7).

Dari kriteria yang disebutkan oleh ulama maupun diindikasikan oleh Alquran, menurut penulis, kriteria utama yang harus dipenuhi seseorang untuk disebut sebagai nabi, minimal ada 3, yaitu: (1) seorang manusia; mendapat wahyu; (3) memiliki mukjizat.

\section{Misi Kenabian dan Ayat-ayat yang Menyebut Nama-nama Nabi}

Nabi adalah manusia yang diberi kemampuan untuk berhubungan dengan Allah dan mengekspresikan kehendaknya. ${ }^{48}$ Pengiriman para nabi atau rasul oleh Tuhan merupakan perwujudan adanya garis perbedaan antara langit dan bumi dan antara Tuhan dan makhluknya. Maka dalam hal ini, Hammudah Abdalati menyatakan bahwa tujuan kenabian adalah menunjukkan apa yang dapat diketahui manusia dan mengajar apa yang tidak atau belum dimengerti. ${ }^{49}$ Maka, seorang nabi adalah manusia yang bertindak sebagai penerima yang menyampaikan pesanpesan Tuhan (baca:wahyu) kepada umat manusia. ${ }^{50}$

Adapun tugas pokok seorang nabi sebagaimana tercantum dalam Alquran adalah memberikan kabar gembira (at-tabsyīr) sekaligus memberi peringatan (al-indzār), QS.al-Baqarah [2]: 213 dan QS. An-Nisa [4]:165., sebagai berikut:

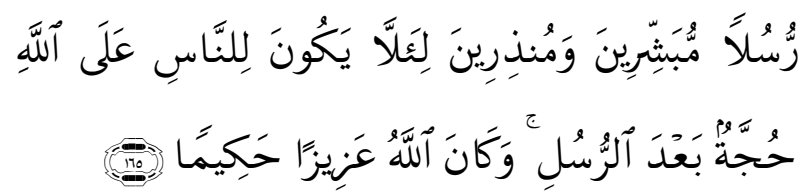

\footnotetext{
${ }^{48}$ Ibrahim Madkour, Filsafat Islam Metode dan Penerapan, (terj) Yudian Wahyudi (Jakarta: CV. Rajawali, 1991), 85.

${ }^{49}$ Hammudah Abdalati, Islam Dalam Sorotan (terj) Anshari Thayib (Surabaya: Bina Ilmu, 1981), 32.

${ }^{50}$ Muthahhari, Falsafah, 9.
} 
Muhammad 'Ali ash-Shabuniy menyebutkan tugas para nabi, yaitu menyelamatkan umat dari cengkeraman syirik dan keberhalaan, kekacauan dan kebejatan moral (QS. AlBaqarah [2]: 213), dengan cara: ${ }^{51}$

1) Mengajak manusia untuk beribadah kepada Allah. Ini adalah tugas dasar dan sasaran para rasul (QS. An-Nahl [16]: 36);

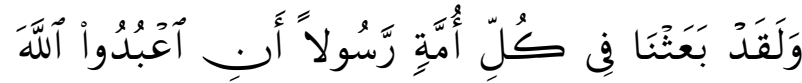

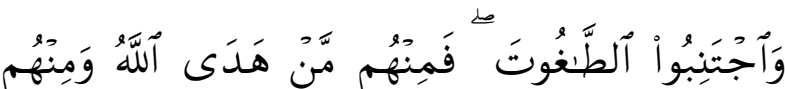

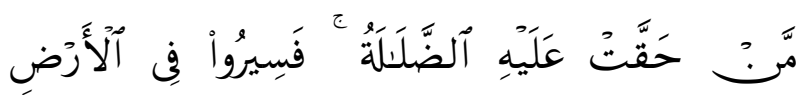

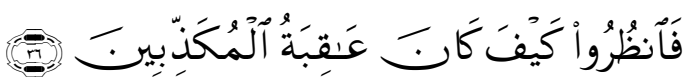

" Kami telah mengutus Rasul pada tiaptiap umat (untuk menyerukan): "Sembahlah Allah (saja), dan jauhilah Thaghut". Di antara umat itu ada orang-orang yang diberi petunjuk oleh Allah dan ada pula di antaranya yang telah pasti kesesatan baginya. Maka berjalanlah kamu dimuka bumi dan perhatikanlah bagaimana kesudahan orangorang yang mendustakan (rasulrasul)."

2) Menyampaikan perintah dan larangan

Allah (QS. Al-Ahzab [33]: 39);

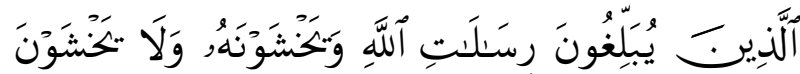

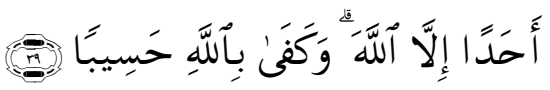

"(yaitu) orang-orang yang menyapaikan risalah-risalah Allah, mereka takut kepadanya dan tidak merasa takut kepada seorang (pun) melainkan kepada Allah, dan cukuplah Allah sebagai pembuat perhitungan."

3) Membimbing manusia dan menunjukkannya ke jalan yang lurus (QS. Ibrahim [14]: 5);

\footnotetext{
${ }^{51}$ Muhammad 'Ali as-Sabuni, An-Nubuunvah wa alAnbiya' (Beirut: 'Alim al-Kutub, 1985), 2830. Bandingkan dengan Al-Asyqar, Ar-Rusul, 4355.
}

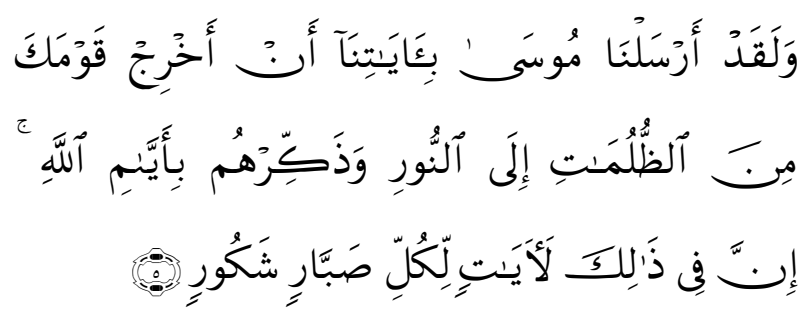

" Kami Telah mengutus Musa dengan membawa ayat-ayat kami, (dan kami perintahkan kepadanya): "Keluarkanlah kaummu dari gelap gulita kepada cahaya terang benderang dan ingatkanlah mereka kepada hari-hari Allah ". Sesungguhnya pada yang demikian itu terdapat tanda-tanda (kekuasaan Allah) bagi setiap orang penyabar dan banyak bersyukur."

4) Memberi teladan bagi umatnya (QS. AlAhzab[33]: 21);

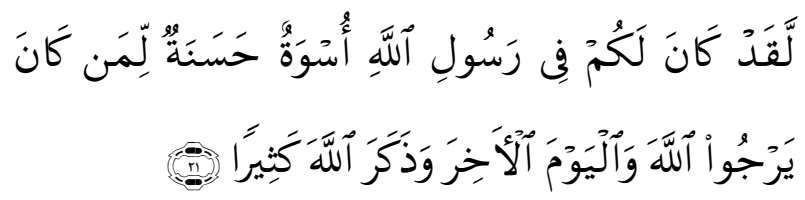

"Sesungguhnya Telah ada pada (diri) Rasulullah itu suri teladan yang baik bagimu (yaitu) bagi orang yang mengharap (rahmat) Allah dan (kedatangan) hari kiamat dan dia banyak menyebut Allah."

5) Menerangkan adanya kebangkitan dari kubur (QS. Al-An'am [6]: 130-131);

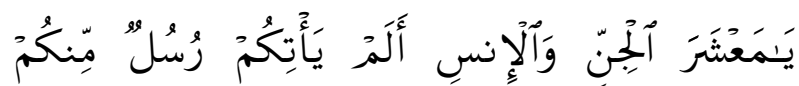

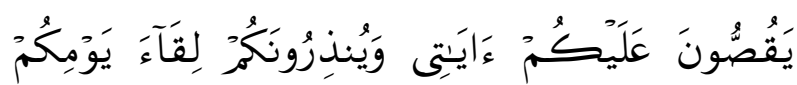

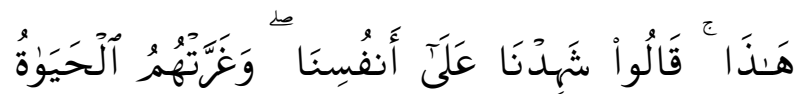

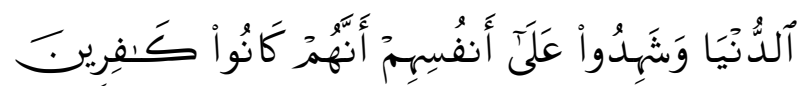

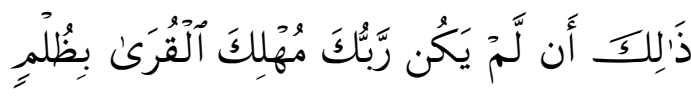

وَأَهْلُهَا غَنَفِلُونَ

"Wahai golongan jin dan manusia, apakah belum datang kepada kalian rasul-rasul dari golongan kamu sendiri, yang menyampaikan ayat-ayat-Ku dan memberi peringatan kepada kalian terhadap pertemuan dengan hari ini? mereka berkata: "Kami menjadi saksi atas diri 
kami sendiri", kehidupan dunia telah menipu dan menjadi saksi atas diri mereka sendiri, bahwa mereka adalah orang-orang yang kafir. Yang demikian itu ialah karena Tuhanmu tidaklah membinasakan kota-kota secara aniaya, sedang penduduknya dalam keadaan lengah."

6) Mengubah kehidupan manusia dari kehidupan yang fana kepada kehidupan yang kekal (QS. Al-'Ankabut [29]: 64);

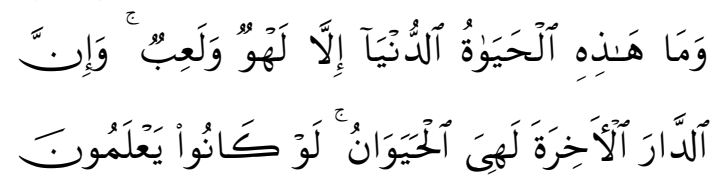

"Dan tiadalah kehidupan dunia Ini melainkan senda gurau dan main-main, dan Sesungguhnya akhirat itulah yang sebenarnya kehidupan, kalau mereka Mengetahui."

Sekarang pertanyaannya adalah apakah tujuan dari misi para nabi dan diwahyukannya firman Ilahi? Tujuan sebenarnya dari misi para nabi adalah membimbing masyarakat dan memberikan kepada mereka kebahagiaan, keselamatan, kebaikan dan kesejahteraan.Para nabi ditunjuk untuk membimbing masyarakat ke arah jalan yang benar, dan memberikan kepada mereka kebahagiaan dan kemerdekaan. ${ }^{52}$

Selanjutnya, Murtadha Muthahhari menunjuk dua konsep yang secara khusus disebut dalam Alquran sebagai misi kenabian. Kedua konsep tersebut adalah: (1) mengajak manusia kearah pengakuan terhadap Tuhan dan pendekatan diri kepadanya, menegakkan keadilan dan kesederajatan dalam masyarakat manusia. Semua ajaran para nabi merupakan semacam perkenalan kepada kedua konsep ini. $^{53}$

Misi pertama mengacu pada Qs. Al-Ahzab [33]: 45-46,Sedangkan misi kedua mengacu pada QS. Al-Hadid [57]: 25:

Berkaitan dengan surat al-Hadid: 25, alThabathaba'i menyatakan bahwa tujuan Allah mengutus seorang rasul dan menurunkan alKitab dan Mizan ialah untuk meneguhkan

\footnotetext{
${ }^{52}$ Muthahhari, Falsafah, 29.

${ }^{53}$ Ibid., 30.
}

keadilan diantara sesama manusia atau untuk menegakkan masyarakat yang adil. Selain itu, ayat tersebut juga mengandung pengertian bahwa diutusnya seorang rasul oleh Allah adalah untuk menguji mereka dalam mempertahankan kebenaran dalam masyarakat. ${ }^{54}$ Makna mizan di sini adalah agama Islam itu sendiri yang mengatur segala persoalan, baik akidah ataupun muamalah. Dengan begitu, tujuannya tidak lain kecuali untuk mencari kebahagiaan hidup baik secara individual maupun sosial, ketika di dunia dan diakhirat. ${ }^{55}$

Menurut al-Tabathaba'i lebih lanjut bahwa diutusnya seorang rasul disertai dengan bukti yang berupa kitab dan mizan untuk menegakkan keadilan diantara sesame umat manusia. Hal ini menunjukan bahwa para rasul datang untuk menyampaikan ajaran tauhid serta muamalah. Misi seorang rasul dapat ditinjau dari dua dimensi, yaitu dimensi horizontal dan dimensi vertikal. Dimensi pertama berkaitan dengan aturan bagaimana melakukan muamalah diantara sesama makhluk termasuk manusia. Dimensi ini diperlukan agar ketika manusia melakukan muamalah diantara sesamanya mampu berbuat adil, tidak saling merugikan antara satu dengan yang lainnya. ${ }^{56}$ Sedangkan dimensi kedua berkaitan terhadap bagaimana berhubungan dengan Tuhan, yaitu menyangkut persoalan ibadah.

Mengajak manusia kepada Tuhan, mengenal-nya dan mendekatkan diri kepadanya, dalam konsep Muthahhari, adalah monotheisme teoritis dan monotheisme praktis yang bersifat individual.Tetapi menegakkan keadilan di tengah-tengah masyarakat berarti menegakkan monotheisme praktis yang bersifat sosial. ${ }^{57}$ Lalu pertanyaannya adalah apakah tujuan sesungguhnya dari misi kenabian adalah monotheisme teoritis dan praktis yang bersifat individual, ataukah monotheisme praktis yang bersifat sosial? Beberapa pendapat bisa dikemukakan di sini.

\footnotetext{
${ }^{54}$ Al-Tabataba'i, Mizan, 19, 177.

${ }^{55}$ Al-Tabataba'i, Mizan, 178.

${ }^{56}$ Al-Tabataba'i, Mizan, 178.

${ }^{57}$ Muthahhari, Falsafah, 30.
} 
Pertama, para nabi mempunyai tujuan ganda, artinya, mereka mempunyai dua tujuan yang berdiri sendiri.Salah satu diantaranya adalah berkaitan dengan kehidupan dan kebahagiaan di akhirat yang bersifat spiritual dan subyektif (monotheisme teoritis dan monotheisme praktis individual). Tujuan yang lain berkaitan dengan kebahagiaan duniawi (monoteisme sosial). Kedua, tujuan sebenarnya dari misi kenabian adalah monotheisme sosial dan prasyarat utamanya adalah monotheisme teoritis dan monotheisme praktis individual. Manusia dapat dikatakan sempurna ketika mampu mengubah diri dari "aku" menjadi "kita" dalam monotheisme sosial, yang tak bisa dicapai tanpa monotheisme teoritis dan monotheisme praktis individual, maka Tuhan menjadikan pengenalan dan penyembahan kepada-nya sebagai prasyarat bagi tegaknya monotheisme sosial. Karena merekalah Islam bisa menjadi seperti sekarang. "Islam has become a system of culture, civilization, political, economic and legal part of the development of world civilization." 58

Ketiga, tujuan sebenarnya misi kenabian adalah agar manusia mengenal Tuhan dan mendekatkan diri kepada-nya, maka monotheisme sosial menjadi prasyarat dan sarana bagi monotheisme teoritis dan monotheisme praktis individual.Argumennya adalah bahwa manusia memiliki privelese khusus, yaitu semua realitas berakar pada Tuhan dan fitrahnya adalah mencari Tuhan sesuai dengan ayat "Dan telah Kutiupkan ruhKu ke dalam dirinya" (QS.Al-Hijr [15]: 29), yakni dunia memiliki sifat "berasal dari-nya" dan "kembali kepada-nya". Maka nilai-nilai sosial seperti keadilan, kemerdekaan, kesederhanaan, demokrasi dan segala moralitas sosial tidak dipandang secara an sich mencerminkan kesempurnaan manusia, tetapi lebih merupakan alat untuk mencapai kesempurnaan.

Keempat, pandangan sebelumnya, yaitu pandangan ketiga menjelaskan bahwa tidak hanya kesempurnaan manusia dan tujuan

\footnotetext{
58 Masripah, "Indonesian Islamic Women Movement (A Case Study of Bkswi West Java)."
}

akhirnya saja, tetapi kesempurnaan setiap manusia terletak dari langkah menuju kepada Tuhan. Pandangan ini menolak pandangan yang mengatakan nabi memiliki tujuan ganda, karena sama halnya mengatakan bahwa keselamatan duniawi adalah tujuan akhir manusia, dan ini adalah pandangan materialistik bertentangan dengan pandangan ketiga, dimana nilai-nilai sosial dan moral merupakan sarana menuju orisinal manusia, yakni menyembah dan beriman kepada Tuhan.

Hubungan antara nilai-nilai moral dan sosial terhadap pengenalan dengan Tuhan dan penyembahannya, merupakan hubungan normatif dan praksis. Jika manusia telah mencapai derajat pengetahuan yang sempurna mengenai Tuhan dan penyembahan kepadanya, maka kejujuran, kemurahan hati, kebenaran, dan keadilan merupakan refleksi darinya. Bagi manusia, moralitas tertinggi adalah menjadi 'seperti' Tuhan. Artinya, pencarian manusia atas nilai-nilai tersebut bersumber pada dorongan yang inheren dalam jati dirinya untuk meraih kualitas-kualitas mirip Tuhan, meskipun manusia sendiri tidak sadar, tetapi akar inheren tersebut, dan bahkan mungkin mengingkarinya dalam pemikiran sadarnya.

Adapun menurut Rahman, ada dua tugas pokok seorang nabi, yaitu tugas terhadap Tuhan dan tugas terhadap sesama manusia. Tugas yang pertama dapat dicermati dari beberapa ayat Alquran seperti QS. AlMu'minun (23): 23. dan QS. al-Baqarah (2): 21.

Sedangkan tugas yang kedua ialah membebaskan pikiran manusia dari berbagai macam takhayul dan mengajak manusia untuk mengamati, menganalisa, dan mengambil kesimpulan/pelajaran dari penalaran deduktif. ${ }^{59}$ Tugas yang kedua ini berkaitan dengan bagaimana pembentukan character building. Oleh sebab itu, terdapat dua hal penting mengenai hal ini, yaitu taqwa dan tazkiyah. Misi yang kedua, yaitu misi kepada sesama manusia jika ditinjau dari surat al-Baqarah [2]: 151

\footnotetext{
${ }^{59}$ Afzalur Rahman, Islam Ideology, 36.
} 
Dalam Islam, seruan kenabian digambarkan sebagai berikut: 1) Dakwah kepada Allah swt; 2) berita gembira dan ancaman at-tabsyīr dan at-tanzīr); 3) janji dan ancaman (al-wa'd dan $a l$-wa'cd) dan lain-lain. ${ }^{60}$ Bahkan dalam Islam, para Nabi termasuk Muhammad adalah tokoh reformasi terhadap sistem kepercayaan dan sosial masyarakat yang dianggap telah menyimpang. Penyelewengan yang dilakukan berdasarkan keimanan dan sosial jelas merupakan bidang garapan reformasi oleh para nabi di suatu masyarakat. ${ }^{61}$

Alquran sebagai sumber otoritatif ajaran Islam tidak secara definitif menyatakan jumlah para nabi dan rasul, dan tidak secara spesifik menyatakan urutan kronologis kenabian .Namun yang pasti, pemahaman dan tafsir atas redaksi tekstual Alquran mengarah ke pemahaman bahwa kenabian yang pertama adalah Adam, yang "dipilih" Allah (QS. Taha [20]: 122; QS. 'Ali 'Imran [3]: 33), "diberi petunjuk" (QS. Al-Baqarah [2]: 38), dan "diberi pengajaran" (QS. Al-Baqarah [2]: 31,33,37), dan terakhir adalah nabi Muhammad (QS. Al-Ahzab [33]: 40).

Selanjutnya, berdasarkan karakteristik di atas tradisi keislaman akhirnya menetapkan jumlah nabi dan rasul yang wajib diimani sejumlah duapuluh lima. Ke25 nabi dalam Alquran itu adalah: Adam, [5] Idris, [6] Nuh, [7] Hud, [8] Shalih, [9] dan Ibrahim, [10]. Selain itu, terdapat juga nama-nama seperti Luth, [11] Ismail, [12] Ishaq, [13] Ya'qub, [14] Yusuf, [15] Ayyub, [16] Syu'ayb, [17] Musa, [18] Harun, [19] Dzu '1-Kifl, [20] Dawud, [21] Sulayman, [22] Ilyas, [23] Ilyasa', [24] Yunus, [25] Zakariya, [26] Yahya, [27] 'Isa, [28] dan Muhammad. [29] Di antara para nabi tersebut, terdapat 5 orang rasul yang disebut ulu al'azm, yang berarti "orang yang berhati teguh" dan memiliki kesabaran yang tangguh.[30] Mereka adalah Muhammad, Ibrahim, Musa, 'Isa, dan Nuh.

Berdasarkan QS. Al-Mu'min [40]:78 yang menceritakan tentang sebagian nabi yang diceritakan dan sebagian lain yang tidak

\footnotetext{
${ }^{60}$ Al-Asyqar, Ar-Rusul, 45-49.

${ }^{61}$ Ziaul Haque, Revelation and Revolution in Islam (New Delhi: International Islamic Publishers, 1992), 4.
}

diceritakan Allah kepada Nabi dalam Alquran, bisa diambil pemahaman bahwa tidak semua nabi di masa lalu disebut dengan namanya masing-masing dalam teks Alquran. Bagaimanapun, tafsir telah menetapkan bahwa garis kenabian diperluas dalam rangkaian keturunan yang bersambung dari Adam hingga Muhammad. ${ }^{62}$

Daftar para nabi yang paling panjang terdapat dalam surat al-Anbiya' ayat 48-91 (periode Makkah pertengahan) dan dalam surat al-An'am ayat 83-86 (periode Makkah akhir), sementara lainnya tertera dalam berbagai surat yang terpisah.

Dalam surat al-Anbiya', disebutkan namanama nabi beserta kelebihan dan keistimewaan masing-masing secara terpisah dalam beberapa ayat, di antaranya adalah: Musa dan Harun (ayat 48-50), Ibrahim (ayat 51-70), Luth (ayat 71 dan 74-75), Ishaq dan Ya'qub (ayat 72-73), Nuh (ayat 76-77), Dawud (ayat 78-80), Sulaiman (ayat 81-82), Ayyaub (ayat 83-84), Ismail, Idris dan Dzul Kifli (ayat 85-86), Dzun Nun ${ }^{63}$ (ayat 87-88), Zakariyya dan Yahya (ayat 8990), Maryam ${ }^{64}$ dan anaknya (Isa) (ayat 91).

Sedangkan nama nabi-nabi yang lain disebut pula secara terpisah di berbagai ayat dan surat.

Menurut Hadiyah Salim, Khaidlir termasuk salah seorang nabi yang ilmunya lebih tinggi dari Musa. ${ }^{65}$ Namun, ia bukanlah seorang rasul. Bey Arifin ${ }^{66}$ bahkan menyebut 'Uzair

\footnotetext{
${ }^{62}$ Namun tentu pendapat para mufassir tersebut belakangan mendapat respon para ulama khususnya tokoh dari Ahmadiyah yang beranggapan bahwa Muhammad bukanlah sebagai penutup para nabi (khatam an-nabiyyin) dan tidak ada nabi lagi sesudahnya.

${ }^{63}$ Nama Dzun Nun dalam tradisi Islam terkenal sebagai nama lain dari nabi Yunus.

${ }^{64}$ Nama Maryam tidak disebut secara ekspilisit dalam ayat ini, ia disebut dengan ungkapan "wa allati ahshanat farjaha fa nafakhna fiha min ruhina". Walaupun demikian, Maryam tetap disebut dalam rangkaian nama-nama para nabi yang notabene adalah laki-laki.

${ }^{65}$ Hidayah Salim, Qishashul Anbiya (Bandung: PT. Al-Ma'arif, 1962), 54.

${ }^{66}$ Bey Arifin, Rangkaian Cerita dalam al-Qur'an (Bandung: PT. Al-Ma'arif, 1971), 62.
} 
yang ada dalam Alquran sebagai nabi (QS. AtTaubah [9]: 30).

Muhammad Ali menyebut nama lain, yaitu Luqman dari Ethiopia dan Dzu al-Qarnayn sebagai nabi. ${ }^{67}$ Hal yang selalu diperdebatkan hingga kini adalah apakah Adam itu seorang nabi, rasul, manusia pertama, atau ketigatiganya? Bahkan muncul pertanyaan apakah Adam itu tokoh historis ataukah hanya simbolis saja? Sebagian pendapat mengatakan bahwa al Qur'an tidak secara tegas menyebut Adam sebagai nabi, melainkan sebagai khalīfah fi al-ardl, wakil Tuhan di bumi. ${ }^{68}$ Namun, karena alasan bahwa ia seorang khalifah di muka bumi itulah, maka ia dapat digolongkan sebagai seorang nabi atau rasul.

\section{SIMPULAN}

Meskipun para ulama berdebat persoalan pengertian nabi dan Rasul, namun argumentasi mereka tentang dua istilah itu tidak mengakibatkan konflik yang signifikan. Karena umumnya mereka hanya berdebat pada fungsi dan pernan nabi berdasarkan kajian pada ayat Alquran dan hadis nabi. Kajian tentang karakteristik kenabian dalam Alquran dan misi kenabian dan Ayat-ayat Alquran dapat memberikan prinspi berpikir untuk membedakan nabi utusan Allah, dan nabi palsu yang belakangan ini sering bermunculan.

\section{DAFTAR PUSTAKA}

Abdalati, Hammudah. Islam Dalam Sorotan (terj) Anshari Thayib. Surabaya: Bina Ilmu, 1981.

Abdullah, Taufik. (ed), Ensiklopedi Tematis Dunia Islam. Jakarta: PT. Ichtiar Van Houve, 2000.

Ali Mahmud, Abdullah bin Zaid. al-Ittihaf Ahfiya' bi Risalah al-Anbiya'. Qatar: Ri'asah al-Mahakim asy-Syar'iyyah wa asy-Syu'un ad-Diniyyah, 1991.

Asyqar, Umar Sulaiman. Al-Rusul wa alRisalat. Kuwait: Maktabah al-Falah, 1985.

\footnotetext{
${ }^{67}$ Muhammad Ali, The Religion of Islam ([t.k.]: [t.p.], 1980), 35.

${ }^{68}$ Keith Crim, The Perennial Dictionary of World Religion, ( [t.k.]: [t.p.], 1989), 187.
}

Aune, David E. "Prophet, Prophecy," Everett Ferguson (ed.), Encyclopedia of Early Christianity, ed. 6. New York and London: Garland Publishing, Inc, 1997.

Bagdadi, Abu Mansur Abdul Qahir ibn Tahir at-Tamimi. Kitab Usul ad-Din. Beirut: Dar al Kutub al-'Ilmiyah, 1981.

Bazdawi, Abu al-Yusr Muhammad bin Muhammad bin Abdul Karim. Kitab Usul ad-Din. Kairo: Dar Ihya al-Kutub al-'Ilmiyyah, 1963.

Casram. "Membangun Sikap Toleransi Beragama." Wawasan: Jurnal Ilmiah Agama dan Sosial Budaya 1, no. 2 (2016): 187-98.

Departemen Agama RI, Ensiklopedi Islam Indonesia. Jakarta: Depag, 1987-1988.

Fahd, T. "Nubuwwa," dalam Bernard Lewis (ed.), The Encyclopedia of Islam, vol. viii (Leiden: t.p, 1995), hlm. 93; Tim Penyusun Kamus Pusat pembinaan dan Pengembangan Bahasa, Kamus Besar Bahasa Indonesia, Edisi Kedua. Jakarta: Balai Pustaka, 1994.

Fatmawati. "Inter-Religious Relations In The Period Of Prophet Muhammad." AlAlbab 5, no. 2 (2016): 175-93.

Gibb, H.A.R. dan J.H. Kramers, Shorter Encyclopedia of Islam. Leiden: E.J. Brill, 1974.

Glasse, Cyril. The Concise Encyclopedia of Islam .San Francisco: Harper \& Row, Publishers, Inc, 1989.

Hornby, A.S. Oxford Advanced Learner's Dictionary of Current English, Jonathan Crowther (ed.) (Oxford: Oxford University Press, 1995).

Ibnu Katsir, al-Bidayah wa al-Nihayah, jilid I, juz I, cet. I. Kairo: Dar al-Taqwa, 1999.

Ibnu Katsir. Tafsir Ibn Kathir dalam CDROOM versi 6.5, Sakhr, 1993-1997.

Ibnu Manzhur, Abdullah. Lisan al-'Arab, juz VI. Beirut: Dar Sadir, [t.t]).

Kerr, David A. "Prophethood" in John L. Esposito (ed.), Oxford Encyclopedia of the Modern Islamic World, vol. 3.

Kodir, Aceng Abdul. "Sejarah Bid'ah: Ashhab AL-Hadith Dan Dominasi Wacana Islam Autentik Pada Tiga Abad Pertama 
Hijriyah." Wawasan: Jurnal Ilmiah Agama dan Sosial Budaya 1, no. 2 (2016): 211-26.

Madkour, Ibrahim. Filsafat Islam Metode dan Penerapan, (terj) Yudian Wahyudi (Jakarta: CV. Rajawali, 1991).

Masripah. "Indonesian Islamic Women Movement (A Case Study of Bkswi West Java)." International Journal of Nusantara Islam 1, no. 2 (2013): 9-21.

Mursyid, Ali, and Zidna Khaira Amalia. "Isra'iliyyat." Wawasan: Jurnal Ilmiah Agama dan Sosial Budaya 1, no. 1 (2016): 94-115.

Murtadha Muthahhari, Falsafah Kenabian. Jakarta: Pustaka Hidayah, 1991.

Muslim bin Al-Hajjaj Al-Nisaburi, Shahih Muslim XV dan XVI .

Nwahaghi, Felix N. "Priesthood and Prophecy in Judeo-Christian Religion," Journal of Dharma 15 (1990).

Putra, Afriadi. "Pemikiran Hadis KH. M. Hasyim Asy'ari Dan Kontribusinya Terhadap Kajian Hadis Di Indonesia." Wawasan: Jurnal Ilmiah Agama dan Sosial Budaya 1, no. 1 (2016): 46-55.

Qosim. "Analysis of Critical Thought Wahbah Wahbah Az-Zuḥailī Concerning Determination Separations." Jurnal Studi
Agama dan Masyarakat 10, no. 2 (2016): 233-56.

Rahardjo, M. Dawam. Ensiklopedi Alqur'an. Jakarta: Paramadina, 1997.

Rahman, Fazlur. Tema Pokok Al-Qur'an, terj. Ahsin Muhammad. Bandung: Mizan, 1996.

Razi, Fakhruddin. Mafatih al-Ghaib al-Tafsir al-Kabir. Kairo: Maktabah al-Amirah asy-Syarqiyah, 1889/1308.

Schleifer, Aliah. Sejarah Hidup Maryam: Sebuah Kajian Tafsir Tematik, (terj.) Ali Masrur. Yogyakarta, UII Press, 2004.

Shabuni, Muhammad 'Ali. An-Nubuwwah wa al-Anbiya'. Beirut: 'Alim al-Kutub,1985.

Solahudin, Muhammad. "Metodologi Dan Karakteristik Penafsiran Dalam Tafsir Al-Kashshaf." Wawasan: Jurnal Ilmiah Agama dan Sosial Budaya 1, no. 1 (2016): 116-26.

Thabari, Abu Ja'far Muhammad b. Jarir, Jami' al-Bayan 'an Ta'wil ay al-Qur'an, vol. 13. Beirut: Dar al-Fikr, 1988.

Wehr, Hans. A Dictionary of Modern Written Arabic. Wiesbaden: Otto Harrassowitz, 1971

Zainudin, Ilmu Tauhid Lengkap. Jakarta: Rhineka Cipta, 1992. 